off, each on its own account, they remain near the mouth of the sporange, each in turn edging its way in between those that have already escaped, with its narrower flagellate (anterior) end inwards. They thus form a hollow sphere, each zoospore rotating round its long axis (radial to the sphere) before encysting in its place. The only explanation that will fit these phenomena is that these zoospores are endowed with a peculiar irritability, in virtue of which they tend to place themselves close together side by side, with their long axes parallel. This irritability is only exerted at a short distance; for if a zoospore be pushed as little as its long diameter away, whether by accident or design, it fails to find its place, but swims off to and fro, instead of rotating in situ, before encysting.

In a critical review of a paper by Rothert, I have given the name "adelphotaxy" to this form of irritability, consisting in the tendency of spontaneously motile cells to assume definite positions with regard to their fellows.

Leaving aside the kindred question of tissue-formation and the processes in the embryo-sac of Phanerogams, adelphotaxy is of rare occurrence in the Vegetable Kingdom. Two good instances occur in the Chlorophytes. In Pediastrum the contents of each cell of the flat disk break up into sixteen (or thirty-two) zoospores, which swarm in the cell and then unite edge to edge to form a new disk. So in each cell of a Hydrodictyon the many thousand zoospores unite end to end to form a new network with hexagonal meshes.

In many of the Myxomycetes the plasmodia aggregate together before fructification to form the compound masses termed rthalia; possibly even the very formation of plasmodia may be regarded as a mode of adelphotaxy.

We may perhaps go a step further and describe the parallel or converging courses of Fungus hyphce to form mycelium-strings, fruitbodies, and pseudo-parenchyma as extreme cases of adelphotaxy.

I think this principle affords a ready explanation of many cases of cellular aggregations in the animal embryo and the formation of the spermatophores of many animals, notably Limicolous worms.

The relations of sexual and isogamous union of gametes to adelphotaxy are obvious; for, though in some cases of sexual union chemotaxy has been shown by Pfeffer to be involved in bringing the active gamete from a distance, that will not cover the actual fusion of the two cells.

What may be the mechanism of adelphotaxy it is impossible to see at present; but its existence as a distinct mode of irritability must now be recognized.

\title{
On the Hersiliidæ, a new Family of Commensal Copepoda.
} By M. Eugine Canu.

The author has discovered at Wimereux two new genera, very nearly allied to Hersilia and commensals of various Invertebrates, 
and he has come to the conclusion that the Hersilians constitute a new family equally distinct from the Siphonostomata and the Peltidians. He considers that in the ontogeny of the most diverse types the first rank in order of appearance is to be given to characters drawn from the buccal appendages, and he has employed these characters prominently in the following diagnoses:-

\section{Family HERSILIIDE.}

Body completely segmented, first thoracic somite united with the cephalic segment. Anterior antennæ 7 -jointed, similar in the two sexes. Posterior antennæ simple, 4-jointed. Mandibles without palpi or masticatory teeth, furnished at their distal extremity with movable accessory pieces in the form of a solid and recurved claw, or of flattened laminæ with the margins notched and denticulate, or of bearded setæ. Maxillæ rudimentary, divided into an inner masticatory lobe and an external palpiform lobe. Paragnathi much developed, concealing the mandibles. Thoracic feet biramose and with triarticulate rami in the first four pairs; simple and flattened in the fifth.

* Mandibles having at their distal extremity a recurved claw and

A. Two accessory pieces:-

1. Of which the anterior is a flattened and notched lamina, and the posterior a small bearded seta. In the male the inner maxillipede is composed of two joints and a greatly reduced prehensile extremity. Genus Hersilia, Philippi.

One species: $-H$. apodiformis, Phil. (=Clausidium testudo, Kossm.), upon the carapace of Callianassa in the Mediterranean and Adriatic.

2. Nearly identical and in the form of flattened denticulate laminæ. The inner maxillipede of the male contains, besides the two basal joints, a long recurved claw. Genus Giardella, Canu.

The genus is dedicated to Prof. A. Giard. There is one species, Giardella Callianasse, Canu, which is abundant in the galleries of Callianassa subterranea in the sands of the Pointe-des-Oies, near Wimereux.

B. Three accessory pieces, of which the anterior is a long, notched, subtriangular lamina, and the others two long bearded and flexible setæ. Genus Hersilioides, Canu.

Three species :-

1. Hersilioides Pelseneeri, Canu, found in the tube of a Clymenian which is very abundant at the Pointe-des-Oies.

2. Hersilioides Thomsoni, Canu, of which three immature ex- 
amples were taken, in the month of April, upon the abdominal feet of Callianassa.

3. Hersitioides Puffini, Thomson (Cyclops Puffini, J. C. Thoms., Proc. Biol. Soc. Liverp. vol. ii. 1887)._-Comptes Rendus, November 12,1888 , p. 792 .

\section{Pebrilla, a new Genus of Infusoria living on the Hermit-crab. By Prof. A. GIard.}

Prof. Giard, at the close of a notice of the species of Folliculina observed on the French coasts, gives a short description of a new form allied to that genus which he proposes to name Pebrilla paguri. He has found this Infusorian on the abdomen of hermitcrabs (Eupagurus Bernhardus) infested by Peltogaster paguri and Phryxus paguri, but does not doubt that it may also exist upon healthy subjects. It forms small colonies placed either in the vicinity of the feet or at the posterior extremity of the abdomen of the hermiterab. These colonies are visible by the naked eye as black patches, which retain their colour even after being long in spirits.

The capsule of Pebrilla is of an oblong-ovate form, with a projecting tubercle at the hinder extremity, within which the actual body of the Infusorian is attached ; it is strongly constricted transversely in the middle, and the aperture is surrounded by a nearly erect or slightly everted collar. The lobes which surmount the mouth of the Infusorian are shorter than in the Folliculince, and the nucleus is very large and moniliform. It is not uncommon to find individuals in a state of bipartition or of gemmiparous reproduction.

Pebrilla paguri, like the Phryxus and Peltogaster, evidently avails itself of the currents of water which circulate along the abdomen of the hermit-crab, and it forms an interesting addition to the long list of commensals of that Crustacean. The specimens on which it was found were collected at Pouliguen and Roscoff, those from the latter locality in 1872, and yet the Infusorians were so well preserved that their vibratile cilia and moniliform nucleus could be clearly seen.-Bull. Sci. de la France et de la Belgique, 1888, p. 316, pl. xx. figs. 1,2 .

\section{On the Nutrition of the Protozoa. By Dr. M. Meissner.}

Dr. Meissner in the first place refers to previous experiments in the feeding of Protozoa, as those made by Count Gleichen-Russwurm in the last century and continued at a later date by Ehrenberg. In both cases the inception of grains of carmine into the body-substance of Infusoria was observed.

The food of the Protozoa is well known to consist of low forms of 


\section{$2 \mathrm{BHL}$ Biodiversity Heritage Library}

Canu, Eugène. 1889. "On the Hersiliidæ, a new family of Commensal Copepoda." The Annals and magazine of natural history; zoology, botany, and geology 3, 67-69. https://doi.org/10.1080/00222938909460298.

View This Item Online: https://www.biodiversitylibrary.org/item/53339

DOI: https://doi.org/10.1080/00222938909460298

Permalink: https://www.biodiversitylibrary.org/partpdf/51337.

\section{Holding Institution}

Smithsonian Libraries

\section{Sponsored by}

Smithsonian

\section{Copyright \& Reuse}

Copyright Status: Public domain. The BHL considers that this work is no longer under copyright protection.

This document was created from content at the Biodiversity Heritage Library, the world's largest open access digital library for biodiversity literature and archives. Visit BHL at https://www.biodiversitylibrary.org. 